\title{
Àwọn 'Ọà Mímọ́: Axé Women in New York City and Their Sacred Paths
}

\author{
Marcelo Niel (iD) https://orcid.org/0000-0002-6796-0298 \\ Departamento de Saúde Coeletiva, \\ Universidade Federal de São Paulo (UNIFESP) \\ marceloniel@mac.com
}

\begin{abstract}
This article is an ethnography of Candomble transnationalization to the city of New York. I describe the journeys of three Brazilian mães de santo (mothers of saints), who have carried their practices and knowledge with them from Brazil. I report how they settled in the city, the dialog with urban space in a megalopolis, the changes that have occurred in the rituals, and the potential transpositions to this new space, their clientele and motivations. It aims to comprehend the importance of the Candomblé itinerary as one of the main components responsible for its maintenance, establishment and expansion in Brazil and in other parts of the world. The connecting points of this article were the stories of three Brazilian mothers of saints who moved to New York City, carrying with them Candomblé rituals practiced in Brazil, transposing them to this new place, having to discuss and rethink their practices in the North American context, reinventing traditional religious settings or, rather, inventing traditions, and dialoguing with the concept of reinvention of tradition, as proposed by Roy Wagner (1975). An important topic found in this reinvention process is a change of hierarchy, as a more horizontal interaction system is adopted by the mothers of saints with their devotees and clients, as opposed to the more vertical model which prevails in the Brazilian terreiros (places of worship). Following the work of the three mothers of saints, aiming to transpose religion to a new context, I describe their encounters with their devotees, who seek health care and well-being through the use of plants and prayers during rituals and religious ceremonies.
\end{abstract}

Keywords: Candomblé, mothers of saints, religion, itineration, women, health care, well-being, strategies of care

Słowa kluczowe: Candomblé, matki świętych, religia, wędrowanie, kobiety, opieka zdrowotna, dobrostan, strategie opieki 
This article aims to present the outcomes of my $\mathrm{PhD}$ research project in the Public Health Department at UNIFESP, resulting from an ethnography of Candomblé migration to the city of New York. I describe the journeys of three Brazilian mothers of saints (mães de santo), who carry their practices and knowledge with them from Brazil. I report how they settled in the city, the dialog with urban space in a megalopolis, the changes which occurred in their rituals, the potential transpositions to this new space, their clientele, and their motivations. In general terms, it is possible to perceive that religious transpositions have always occurred, but there has been a remarkable increase in the transit of African-derived religions, Afro-Brazilian and Afro-American, to regions and countries where Western culture prevails, according to Segato. ${ }^{1}$ When Candomble moves to a different place, there is a meeting process to several collectivities, with distinct ethnical and religious bounds, a very common phenomenon in contemporary societies. ${ }^{2}$ Moreover, the establishment of religious practices in this new place could have totally different connotations regarding identities and resulting discourses within the national order, demanding an elaboration process within this new diversity.

In this Candomble journey to the United States, as well as to other parts of the world, as other researchers have demonstrated, ${ }^{3}$ the intense capacity of negotiation and reinvention stand out. ${ }^{4}$ The observed changes are not caused by some sort of degradation of something that must remain unchanged, but by a type of reinvention needed to preserve the ritual. ${ }^{5}$ In other words, differences in rituals can be analysed as variations of religious elements incorporated from different faith systems. Therefore, instead of forcing a religious standardization legitimized by many anthropologists, it is possible to preserve the ritual practice complexity which is, as noted, constantly being transformed and renegotiated. ${ }^{6}$

At the beginning of the research, it was believed that being initiated could facilitate ones immersion into the field, mainly because it would provide some sort of

${ }^{1}$ R.L. Segato, Santos e daimones: o politeísmo afro-brasileiro e a tradição arquetipal, Brasília 2005.

${ }^{2}$ Idem, Una vocación de minoria: la expansión de los cultos afro-brasilenos en laArgentina como processo de reétnización, [in:] idem, La Nación y sus Otros: raza, etnicidad y diversidad religiosa en tiempos de polàticas de la identidad, Buenos Aires 2007, pp. 243-273.

3 J. Bahia, De Miguel Couto a Berlim: a presença do candomblé brasileiro em terras alemãs, [in:] Migração e globalização: um olhar interdisciplinar, G.M.S. Pereira, J.R.S. Pereira (eds.), Curitiba 2012, pp. 86-104; S. Capone, Searching for Africa in Brazil - Power and tradition in Candomblé, LondonDurham 2010; M. Goldman, Histórias, devires e fetiches das religiões afro-brasileiras: ensaio de simetrização antropológica, "Análise Social” 2009, no. 190, pp. 105-137; E. Gomberg, Hospital de orixás - Encontros terapêuticos em um terreiro de candomblé, Edufba 2001; A. Oro, As religiões afro-brasileiras: religiões de exportação, cit. by: J. Bahia, O Candomblé em terras alemãs. Domínios da Imagem, "Religião, migração e cultura. Imagens da fé" 2016, vol. 10, no. 18, pp. 86-104; I. Pordeus Jr., Uma casa luso afro-portuguesa com certeza: emigrações e metamorfoses da umbanda em Portugal, São Paulo 2000; R. Prandi, Segredos guardados - Orixás na alma brasileira, São Paulo 2005; V.G. Silva, Orixás na metrópole, Petrópolis 1995.

${ }^{4}$ M.J. Herskovits, The Social Organization of the Afrobrazilian Candomblé, "Phylon" 1956, vol. 17, no. 2, pp. 147-166; S. Capone, op.cit.

${ }^{5}$ I. Sjorslev, The Myth of Myths and the Nature of Ritual: Ideology and Practice in Afro-Brazilian Religion, "Folk" 1989, no. 31, pp. 125-123.

${ }^{6}$ S. Capone, op.cit. 
knowledge about Candomblé's own language, and for being considered as an equal by the priestesses. I consider myself partially successful at it. I say "partially" because in Candomblé, the awo, which means secret or mystery in Yoruba, is the key to maintaining power, and I noticed each priestess has her own systems of secrets. As I reach the mystery, I face a great obstacle to overcome, which is the process of choosing what can and cannot be revealed, to avoid the risk of betraying an ethnical principle of the studied universe and the trustworthy relationship with my interlocutors. I cannot help but wonder whether immersion into this field unveils another type of secret, the illegality of these practices in a foreign land, where my presence, as an "intruder," is likely to be repelled. Awo, as sacred secret, is articulated to the aspect of illegality which also preserves the sacred.

It is known that to truly immerse into the field the researcher must be "affected" by this contact, as Favret-Saada described, when the researcher is accepted and considered as an equal, in my case, a brother of saints, a follower initiated in the religion, receiving the permission, or agô in Yoruba. ${ }^{7}$ Because this is how religion works: nothing is done without asking permission. And this permission was given to me in different ways, through cowrie-shells divination, by referring to someone they trusted or through a spiritual entity's consent, which always form the permission given by Orisha himself.

Igbá, Yoruba for "time," deeply influenced the conducting of the research. Many Candomblé priests, and therefore initiated people and followers frequently assert that Candomble time is different from the chronological time of the Western world. There is time for everything, everything has the right time and when we are able to understand how time works in the Candomble imaginary, raising the need to learn to wait for appropriate permissions, that is when "magic," or "bewitching" occurs, receiving the ago, the permission to access the awo, the secret.

\section{Candomblé as a place to seek well-being and good health}

The social sciences have been engaged in an intense dialog with religions for a very long time. Regarding Candomblé, in particular, this intense relationship has deeply contributed to Candomblé's acceptance and appreciation as an important Brazilian religion in our society, for disseminating its elements in our culture, such as through music, cooking or popular national festivals.

The main role of this therapeutic-religious system is to make the individual's life better understood and capable of being borne, helping them to interact in this context, aiming for religion to provide a cosmovision of the universe itself, where it is possible to build a supporting model to face reality. ${ }^{8}$ Followers, initiated people, and clients use showers with herbs or other elements, ebós (cleansing and strengthening rituals), and consultations among other strategies to improve health. According to

7 J. Favret-Saada, Être Aecté, "Gradhiva: Revue d'Histoire et d'Archives de l'Anthropologie" 1990, vol. 8, pp. 3-9.

${ }^{8}$ E. Gomberg, op. cit.. 
Santos, religious practices similar to Candomblé aim to prevent misfortune and to provide luck. ${ }^{9}$ In other words, religious activity seeks to keep away threats to vulnerabilities of the body (disease, infertility, defeat, jealousy, death), and to bring fortune: health, fertility, spiritual safety, prestige, and success.

Luckily then, the differences from the alleged revealed religions, such as Islam or Christianity, are preserved, as Candomblé is concerned with life sustainability, as opposed to those ones more interested in eternal soul salvation on another spiritual level. Therefore, it is clear that the terreiro is also a place of health, becoming itself a healing agency, but also articulated with a biomedical system somehow. And this is not a current phenomenon nor restricted to the cult followers: there are historical reports, since colonial times, that Candomblé was not only a type of ethnic medicine for ancient slaves or poor people deprived of classic medicine; various members of society, including wealthy people of European descent, have sought the services offered through these practices.

\section{The itinerary}

Considering the transit of Candomblé elements being carried in the luggage of every mother of saints, it is inevitable to wonder what happens with them and Candomble during the comings and goings to New York City, in this new space, with new forms of socialization. Therefore, the concept of itineration, suggested by Ingold, ${ }^{10}$ is so instructive for such a complex phenomenon. Ingold considers an anthropology through topics of life and growth in an opened process, where people cannot be analysed separately from the environment: both the human and the environment are in a development process and they are its products. In fact, Candomblé, being a religion with an open codex, where changes and reinvention are fundamental to its continuity, has its own way to move forward, what the author calls flaneur, as something inherent to the religion itself, full of improvisation and creativity. Although the newcomer's itineraries, geographical and religious origins differ, as do their reasons to migrate, the journey and the transposition of Candomble elements is the common point between them.

They consider their journey to be an evolutive process of the religion itself because it is in line with Orisha's wishes, being part of his mission, to preserve religion alive, the same way African slaves during the colonial period brought their religious luggage to Brazil, reinventing traditions. As they arrived in New York City, they faced many real difficulties to perform their rituals: shortages or lack of certain materials, difficulties in performing rituals in public spaces, being prohibited by local laws, and in many cases, due to adverse weather conditions, the problematic issue of disposing ritual materials in public spaces, noise issues during public ceremonies,

\footnotetext{
${ }_{9}$ E.F. Santos, O poder do candomblés - Perseguição e resistência no recôncavo da Bahia, Salvador 2009.

${ }_{10}$ T. Ingold, Ambientes para la vida. Coversaciones sobre humanidad, conocimiento e antropología, Montevideo 2012.
} 
and the usage of animal sacrifice in some rituals. The three priestesses decided to reinvent rituals and materials, in most cases, not accepted by priests in Brazil. Many Brazilian priests consider this journey to be against and harmful to their religious principles, often labeling these practices in a derogatory way, suggesting the priestesses' main motivation is to earn money.

In fact, this religion reinvention process in New York City, formed by the three mothers of saints, is an integrated part of an emerging itinerary which, step by step, combines each one's religious and personal life elements in an ongoing "bricolage" process as their stories are being constantly created and recreated, as Pinho and Pereira defined. ${ }^{11}$ We can say that although this journey draws many elements from wills, wishes, and aspirations each mother of saints, their choices are affected by the Orisha's determinations. Therefore, their realities are changed, and their identities are gradually rebuilt, as Iriart $^{12}$ emphasized, criticizing the current sociocultural order, creating inside them a place for exchanging experiences.

\section{Mothers of saints in NYC: rebel goddesses in Manhattan}

As each priestess' personal journey is analysed, including this meeting with Candomblé and the migration to New York City, it was possible to elaborate some routes of meanings that constituted them as priestesses. On one hand, despite coming from distinct personal life experiences, their Candomblé practices are very similar regarding their relationships with others, clients or devotees, probably affected by the more autonomous working process of someone who lives in a city like New York. Considering their journeys, it is evident to notice how these women possess strength, daring, courage and creativity, and such attributes have built, in my imagination, a heroic journey, like Orisha's journeys. In Candomblé, the Orisha, in many myths, appears initially as a mortal person who was divinized, in other words, became a God or Goddess due to his or her heroic acts. ${ }^{13}$ Therefore, there is, symbolically, a demigod aspect in a father or mother of saints.

Regarding their relationship with Candomble in Brazil, there is, among them, a strong impulse of liberation from hierarchical patterns prevailing in the religion and each one dared, on her own way, to transform practices as priestesses, establishing a more horizontal and equal relational system with clients and devotees. However, even though reduced, the sense of power is present in their imaginary, as that power becomes an organizing principle in the lives of who seek their services, and not rarely. As Dumont stated, a hierarchy of ideas, things and people, is essential to

11 P.A. Pinho, P.P.G. Pereira, Itinerários terapêuticos: trajetórias entrecruzadas na busca por cuidados, "Interface - Comunicação, Saúde, Educação" 2012, vol. 41, no. 16, pp. 435-450.

12 J.A.B. Iriart, Les femmes dans le candomblé. Expérience religieuse et idiome de la possession dans la vie des femmes de Cachoeira, $\mathrm{PhD}$ thesis, Brésil, Département d'Anthropologie, Faculté des Arts et des sciences, 1998, http://www.collectionscanada.gc.ca/obj/s4/f2/dsk2/ftp02/NQ43015.pdf [access: 01.07.2017].

13 R. Prandi, Mitologia dos Orixás, São Paulo 2003. 
social life and, in many cases, it will relate, somehow, to power. ${ }^{14}$ Thus, even though this is a very different context, in another territory and with other meanings, it is a place where women's power is observed, as Silva emphasized. ${ }^{15}$ The three mothers of saints are, in my point of view, great Secret Ladies or Àwon İyá Awo in Manhattan. Moreover, they also have the important duties of intermediation (ilàjà) and transposition (itúmo), which involved with awo establish a religion working system and the maintenance of Axé in this new place.

The three priestesses described a feeling, at the beginning of their religious journey, a sensation of estrangement as they were informed that they had a priestly mission. However, as they went on, performing their practices and accepting the mission given by the Orishas, the feeling of power, while being "crowned" as priestesses, gradually becomes internalized, to a point where they become the Orisha himself, regarding his capabilities and personality traits. There is, according to Silva, a Candomblé women's - in particular the priestesses' - relation to aspects of the feminine which break the Western ideal of femininity, especially concerning aspects such as passivity, domesticity, and obedience. ${ }^{16}$ Therefore, these women rely on warrior goddesses' archetypes as strong mothers, fearful and sensual women, gifted with great power, life keepers and controllers of destruction, all of which can coexist with the "softer" aspects related to mothering.

Pimpa, Regina and Bárbara merge the reasons why they migrated with religious epiphanies, which explains this journey's missionary vein, through the Orisha's wish to expand cults to other parts of the world. In this journey to a foreign land, they recreate the knowledge they brought with them, keeping what they could, retelling stories, rethinking and reinventing their practices, and teaching new followers in order to continue the religion. As they mediate these reinventions, they also started a process beyond the practices' limits, affecting and forcing them to "translate" themselves. Reinventing Candomblé could be comprehended as a process in the invention of tradition, suggested by Wagner, as a dynamic, creative and necessary process to keep a cultural element alive. ${ }^{17}$

In these constant practices transpositions and, consequently, in the reinvention of this complex religious system, they continue to call what they do "Candomblé." There is permission to reinvent. Permission, on one hand, given by the Orishas themselves, through cowrie-shells divination: they reveal if they are or are not satisfied with their practices. This permission is constantly justified, however, by the journey of religious and cultural elements brought by enslaved Africans, merging pieces of belief and different Gods to originate Candomblé. Although they call their practices "Candomble," it is possible that, according to Pimpa, this adaptation is slowly becoming more and more distant from the practices performed in Brazil and creates a new form of religion, not exactly of African origins, but of Afro-Brazilian origins.

\footnotetext{
${ }^{14}$ L. Dumont, Homo Hierarchicus: o sistema de castas e suas implicações, São Paulo 1997.

${ }_{15}$ M.V. Silva, Gênero e religião: o exercício do poder feminino na tradição étnico-religiosa iorubá no Brasil, "Revista de Psicologia da UNESP" 2010, no. 9(2), pp. 128-137.

16 Ibidem.

${ }^{17}$ R. Wagner, The Invention of Culture, Chicago 1975.
} 


\section{Cowrie-shells divination and magical prescriptions}

According to Beniste, ${ }^{18}$ cowrie-shells divination is the main oracular system of the religion, one performed only by priests. Usually, this is the first contact the care-seeker will have with the religion and the priest, and this consultation will determine the person's needs according to the vision of this religious system. The consultation will determine who is the Orisha, called "saint of head," leading aspects such as personality, paths, destinies and even physical features.

It has been noticed that the three mothers of saints respect and maintain their relationship with cowrie-shells divination, using it to unveil Orisha's wishes to a specific person. In Brazil or in New York City, it is important to notice cowrie-shells divination itself has therapeutic effects on that person, as this is, firstly, a conversation, a type of counselling, besides all the possible magical prescriptions originating from this oracular consultation.

From cowrie-shells divination, magical prescriptions are given, leading to the "treatment" time itself. Showers, praying, ebós, boris, incenses, magical powders and herbs are used in different ways to create customized prescriptions for each client and devotee. The three mothers of saints report the same type of difficulty in finding the right ingredients, especially fresh plants at certain times of the year. This difficulty has been alleviated in recent years; almost all the necessary products are obtained from Brazilian, African or Hispanic merchants, sometimes even in other cities or states, or delivered by mail. When a specific product is not found, they must find replacements, not aleatory, but permitted or accepted by Orishas through cowrie-shells divination or their own experiences.

\section{The need for initiation}

There are divergences among the women regarding the need of a person's initiation after the cowrie-shells divination. Pimpa and Bárbara consider it impossible to perform the initiation or "feitura" correctly or as it is done in Brazil, because of the difficulties in finding the proper materials, for not having a typical terreiro and even for the difficulties in performing animal sacrifice which, even though it is not prohibited in the city, is always a delicate issue, as it somehow makes the priest more vulnerable and susceptible to lawsuits. Both reported they prefer to send a devotee in need of initiation to fathers of saints in Brazil. Regina has a more daring attitude: she does not only believe it is possible to perform an initiation process in New York City, but she has performed two group initiation process, also called "boats," one with 13 people in New York City and a similar one in California.

However, no matter how much the priestesses reinvent their ritual practices, the knowledge of the existence of Axé, which is characterized by the vital force to sustain

18 J. Beniste, Jogo de Búzios: Um encontro com o desconhecido, Rio de Janeiro 1999. 
the world, ${ }^{19}$ remains unchanged. Axé is the main luggage brought by the mothers of saints to New York City. Axé, a dynamic force which adapts, grows or becomes smaller, expands or shrinks, gets fed or feeds people, sacred objects or places, is, without a doubt, the main and most frequent element in this journey. For this reason, I called them Àwon İyá Àsẹ, the Axé Ladies in the Big Apple. Axé is not an autochthonous force or energy; it is carried, planted, seeded, cultivated, multiplicated, divided between priests, initiated in people, devotees and clients, and transferred to people, objects and territories. According to Prandi, "You have Axé, you use it, you wear it off, it restores, it accumulates. Axé is the origin, it's the roots brought by ancestors. ${ }^{.20}$ It is the best way to balance health and well-being, because, for Candomblé, diseases do not have only physical causes; to the contrary, they are consequences of a process of Axé imbalance. ${ }^{21}$

Many authors have carried out studies regarding the importance of Candomblé in Brazil as a complex health care system, ${ }^{22}$ and, according to the mothers of saints, people who live in New York City, either Brazilian immigrants or not, seek their services as a way to reconnect with their spirituality, as much as to minimize or heal physical or mental discomforts, through "affectionate work," as Arouca ${ }^{23}$ described, characterized by different types of care differing from the biological model proposed by contemporary medicine.

At any rate, they did not consider the need of having a specific space to perform Candomblé as fundamental: opinions differ only on the matter of initiation, or feitura. In general terms, the priestesses share the opinion that feitura is not the only alternative, essential to every person who seeks their services; it seems most people seek help to deal with, in a more comfortable way, daily life difficulties and in some cases the initiation process will be prescribed only when necessary. On that basis, the mothers of saints seem to be more similar to African "Babalawos," constantly moving around and travelling, from home to home, from client to client, carrying cowrie-shells and magical tools with them, than to a typical Brazilian priest who owns a place of worship and performs most of the rituals there.

It is possible to comprehend, in this context, that divergences in conduct can originate from the knowledge learned from their priests, and their native houses of saints (terreiros); on the other hand, from their life stories, their different ways of adapting to a new space result in particular methods of elaboration and reinvention of their religious practices. Bahia, while studying Afro-Brazilian religion transnationalizations and their adaptations, demonstrates that practice divergences and perspectives, not only in the initiation process, but many other practices related to religion, also emerge in these new sceneries. ${ }^{24}$

19 J.E. Santos, Os Nagô e a Morte: Pàde, Àsèsè e o Culto Égun na Bahia, Petrópolis 2008.

${ }^{20}$ R. Prandi, Os candomblés de São Paulo: a velha magia na metrópole nova, São Paulo 1991.

${ }^{21}$ A.K.M. Pinezi, E.F.C. Jorge, Doença, saúde e terapias: aproximações e distanciamentos entre o Candomblé e o Neopentecostalismo, "Caminhos" 2014 , vol. 12, no. 1, pp. 65-78.

${ }_{22}$ E. Gomberg, op. cit.; F. Lima, As quartas-feiras de xangô - Ritual e cotidiano, João Pessoa 2010; E.F. Santos, op. cit.; J. Ziegler, Os vivos e a morte, Rio de Janeiro 1977.

${ }^{23}$ S. Arouca, O Dilema Preventivista - Contribuição para a compreensão e crítica da Medicina Preventiva, São Paulo-Rio de Janeiro 2003.

24 J. Bahia, De Miguel Couto..., op.cit. 
In conclusion, the reinvention of Candomblé in New York City, as a typical movement of transnationalization, figure an important inscription of the religion in this new land, working as ethnical fringes or "ethnoscapes," ${ }^{25}$ transforming and being transformed, step by step. It is clear these priestesses' ritual practices create a sophisticated therapeutic system which involves comforting, counselling, as well as many therapeutic prescriptions ranging from simple to complex, aimed at re-establishing mental and physical health, minimizing suffering and promoting improvement of life quality, focusing always on the maintenance of Axé as the primary vital force, the key element to comprehend the maintenance of Candomblé and how it works in Brazil, in New York City and many parts of the world.

\section{References}

Amaral R., Mães-de-Santo, mães de tanto. O papel cultural das sacerdotisas dos cultos afrobrasileiros in Os Urbanitas, "Revista de Antropologia" 2007, vol. 4, no. 6, dez/2007.

Appadutai A., As Dimensões Culturais da Globalização, Lisboa 1996.

Arouca S., O Dilema Preventivista - Contribuição para a compreensão e crítica da Medicina Preventiva, São Paulo-Rio de Janeiro 2003.

Bahia J., De Miguel Couto a Berlim: a presença do candomblé brasileiro em terras alemãs, [in:] Migração e globalização: um olhar interdisciplinar, G.M.S. Pereira, J.R.S. Pereira (eds.), Curitiba 2012, pp. 86-104.

Bahia J., O Candomblé em terras alemãs. Domínios da Imagem, "Religião, migração e cultura. Imagens da fé" 2016, vol. 10, no. 18, pp. 86-104.

Beniste J., Jogo de Búzios: Um encontro com o desconhecido, Rio de Janeiro 1999.

Capone S., Searching for Africa in Brazil - Power and Tradition in Candomblé, London-Durham 2010.

Cossard G.O., Awô. O mistério dos Orixás, Rio de Janeiro 2006.

Dumont L., Homo Hierarchicus: o sistema de castas e suas implicações, São Paulo 1997.

Favret-Saada J., Etre Aecté, "Gradhiva: Revue d'Histoire et d'Archives de 1'Anthropologie" 1990, vol. 8, pp. 3-9.

Goldman M., Histórias, devires e fetiches das religiões afro-brasileiras: ensaio de simetrização antropológica, "Análise Social” 2009, no. 190, pp. 105-137.

Gomberg E., Hospital de orixás - Encontros terapêuticos em um terreiro de candomblé, Edufba 2001.

Herskovits M.J., The Social Organization of the Afrobrazilian Candomblé, "Phylon" 1956, vol. 17, no. 2, pp. 147-166.

Ingold T., Ambientes para la vida. Coversaciones sobre humanidad, conocimiento e antropología, Montevideo 2012.

Iriart J.A.B., Les femmes dans le candomblé. Expérience religieuse et idiome de la possession dans la vie des femmes de Cachoeira, $\mathrm{PhD}$ thesis, Brésil, Département d'Anthropologie, Faculté des Arts et des sciences, 1998, http://www.collectionscanada.gc.ca/obj/s4/f2/dsk2/ftp02/NQ43015. pdf [access: 01.07.2017].

Lima F., As quartas-feiras de xangô - Ritual e cotidiano, João Pessoa 2010.

Mandarino A.C.S., Gomberg E., Candomblé, corpos e poderes, "Perspectivas" 2013, vol. 43, pp. 199-217.

25 A. Appadutai, As Dimensões Culturais da Globalização, Lisboa 1996. 
Pinezi A.K.M., Jorge, E.F.C., Doença, saúde e terapias: aproximações e distanciamentos entre o Candomblé e o Neopentecostalismo, "Caminhos" 2014, vol. 12, no. 1, pp. 65-78.

Pinho P.A., Pereira P.P.G., Itinerários terapêuticos: trajetórias entrecruzadas na busca por cuidados, "Interface - Comunicação, Saúde, Educação" 2012, vol. 41, no. 16, pp. 435-450.

Pordeus I. Jr., Uma casa luso afro-portuguesa com certeza: emigrações e metamorfoses da umbanda em Portugal, São Paulo 2000.

Prandi R., As religiões negras no Brasil: para uma sociologia dos cultos afro-brasileiros, "Revista USP” 1996, no. 28, pp. 64-83.

Prandi R., Mitologia dos Orixás, São Paulo 2003.

Prandi R., Os candomblés de São Paulo: a velha magia na metrópole nova, São Paulo 1991.

Prandi R., Segredos guardados - Orixás na alma brasileira, São Paulo 2005.

Santos E.F., O poder do candomblés - Perseguição e resistência no recôncavo da Bahia, Salvador 2009.

Santos J.E., Os Nagô e a Morte: Pàde, Àsèsè e o Culto Égun na Bahia, Petrópolis 2008.

Segato R.L., Santos e daimones: o politeísmo afro-brasileiro e a tradição arquetipal, Brasília 2005.

Segato R.L., Una vocación de minoria: la expansión de los cultos afro-brasilenos en laArgentina como processo de reétnización, [in:] idem, La Nación y sus Otros: raza, etnicidad y diversidad religiosa en tiempos de polàticas de la identidad, Buenos Aires 2007, pp. 243-273.

Silva M.V., Gênero e religião: o exercício do poder feminino na tradição étnico-religiosa iorubá no Brasil, "Revista de Psicologia da UNESP" 2010, no. 9(2), pp. 128-137.

Silva V.G., O antropólogo e sua magia, São Paulo 2000.

Silva V.G., Orixás na metrópole, Petrópolis 1995.

Sjorslev I., The Myth of Myths and the Nature of Ritual: Ideology and Practice in Afro-Brazilian Religion, "Folk" 1989, no. 31, pp. 125-123.

Wagner R., The Invention of Culture, Chicago 1975.

Ziegler J., Os vivos e a morte, Rio de Janeiro 1977. 